\title{
DERIVATIONAL AFFIXES IN WRITING ANALYTICAL EXPOSITION TEXT
}

\author{
${ }^{1}$ Destriani Simaremare, ${ }^{1,2}$ Dumaris E. Silalahi, \& ${ }^{1}$ Lydia Purba \\ ${ }^{1}$ FKIP, Universitas HKBP Nommensen, Medan, Indonesia \\ ${ }^{2}$ Corresponding Author Email: dumaris.silalahi@uhn.ac.id
}

\begin{tabular}{l}
\hline \hline Article Info \\
\hline Article History \\
Received: October 2020 \\
Revised: December 2020 \\
Published: January 2021 \\
\hline Keywords \\
Derivation affixes; \\
Types of Affixes; \\
Analytical Exposition Text;
\end{tabular}

\begin{abstract}
This research is about the analysis of derivational affixes in Writing Analytical Exposition Text. It intended to describe the process of derivational affixes and to find out the types, the structure, and the functions of each derivational affixes in writing analytical exposition text by the twelve grade students from YouTube. The qualitative method was used to investigate derivational affixes in writing analytical exposition text. The data were collected by documented study. They were collected from students' results of making texts about analytical Exposition text, finding the text about analytical exposition, choosing the text that relevant with Corona virus disease, and the last searched the words that contain derivational affixes, the researcher identified. The results of this study showed that derivational affixes were found in writing analytical exposition text. There were three types of affix used. They were prefix, suffix, and circumfix. There was no infix used. Kinds of prefix found were pre-, dis-, re-, on-, under-, inter-, micro, trans-, over-, al-, In-, out-. Kinds of suffix found were -ment, -ly, -ness, -ion, -y, er, -ive, -ous, -ant, -ious, -ation, -en, -wards, -ition, -ed, -est, -ies, -ities -ily, ence, -ing, -side. Kinds of circumfix found were Trans-ed, In-ation, inter-ion, dis$e d$, re-ation, un-y, anti-ion, un-ed, in-ly, trans-ion, inter -ed, re-ing, trans-ing, in- ing, in-ent. The function of derivational affixes found in writing analytical exposition were verb formation, noun formation, adjective formation, and adverb formation, in which sometimes in the process of word formation, it did not always change the part of speech even though it had got the addition of affixes, such as noun into noun, verb into verb, and adjective into adjective. There were many derivational affixes. Moreover, suffix -ing to form a noun and -ly to form an adverb the most dominant affixes.
\end{abstract}

How to cite: Simaremare, D., Silalahi, D.E., \& Purba, L. (2021). Derivational Affixes In Writing Analytical Exposition Text, JOLLT Journal of Languages and Language Teaching, 9(1), 44-52. DOI: https://doi.org/10.33394/jollt.v\%vi\%i.2999

\section{INTRODUCTION}

Derivation is one of morphological system which has to be understood well by the English learners. It is said by the reason that derivation gives several of meaning into the root of words. Derivations are words derived from one stem or base word by attaching to them affixes, both prefixes and suffixes. These affixations are used to make new words in English. These are often used to make words of a different grammatical category from the root, for example the addition of suffix -ify to noun 'beauty' will form a new verb 'beautify' which means 'to make beautiful'.

Derivation is actually attaching the root of word by adding an affixes and produce new lexeme or change word class. Lieber (2009:53) stated that derivation is the process by which the words are formed and create new lexemes, so before making new lexemes, they have to have "the base" because it is the core of word which can be turned into different word by attaching affixes. Moreover, when a base added by derivational affixes, it adds the meaning. 
Affixation is a subject which is difficult to be understood by the students. According to McCarthy (2006) as cited in (Herman, 2015), affixation is the process for a bound morpheme that is attached or joined before, after or within to a base, it means simple structure (as in „happy“e, the base to which -ness is attached to yield "happiness"), or complex structure (as in "happy"e, the base to which un- is attached to yield, "unhappiness"). Affixation as one of the morphological processes will generate new word when affixes are attached to stems (Ambarita, 2018c: 75).

In almost all research, affixation is used to investigate the structure of word or known as forming word. Aryati (2014) only uses derivational affixes process in English language. The researcher only describes the process of word class changing derivational affixes in English word. Therefore, Aryati (2014) becomes the core of my study to continue her research to analyze derivation and inflection affixes. This present study fill the gap by investigating derivational and inflectional of English affixes to English language and analyze the process and the function of derivational and inflectional affixes.

Derivational affixation can occur with unlimited set of words. Maharsi and Purwaningtyas (2017:26) state that derivational morpheme is a type of bound morpheme which develops or creates new words by either changing the class of words or forming new words. Based on these statements, as long as individuals who are learning English as a second language realize morphemes in complex words, they may learn and acquire vocabulary easily. A morpheme is the smallest grammatical unit in a language. It can be divided into two categories, they are free morpheme and bound morpheme. A free morpheme can function independently as words (e.g town and dog), e.g: townhouse and dog house. Therefore, bound morpheme appears only as part of words always in conjunction with a root and sometimes with other bound morpheme. According to Fromkin et al. (2011: 41) morphology is the study of internal structure of words and of the rules informing words.

Based on the explanation, the researcher is interested to analyze the affixes by using derivational affixes theory in this study. The researcher chooses analytical exposition text taken from the You Tube. The researcher taken the all text that relevant with covid-19, the researcher focuses on derivation affixes that investigate in English affixes. However the researcher analyzes not only on types of derivational affixes found, but also analyzes, the structure of form and the function found in analytical exposition text.

To explain more about the derivational affixes the researcher used Lieber (2009). The researcher analyzed three problems, such as the types, the structure of form, and the function found in analytical exposition text that relevant with corona virus disease 2019.

\section{Morphology}

Morphology is the study of word formation, including the ways new words are coined in the language of the world, and the way forms of words are varied depending on how there are used in sentences". It means that Morphology is the science that studies about the word, a word that has innovation when used in sentences.Morphology became an important study in Linguistics in case of word formation. The reason why morphology became an important thing in language because morphology has a role to form of new word to the language. (Lieber, 2009:2).

\section{Morpheme}

Morpheme is the part of morphology. It increases knowledge of vocabularies. According to Lieber (2009:32), morpheme is the meaningful units that are used to form words". The form of morpheme is different from form of word. A word absolutely can stand alone and has lexical or functional meaning, but a morpheme can stand alone if the morpheme in the form of free morpheme and cannot stand alone if the morpheme in the form of bound morpheme such as /-ness/, /-ion/, /ment/, /en-/ are called bound morpheme. Such as word refresh, re /fresh, quickly, quick / ly, globalization, 
global / iza /tion. They are called morpheme. The combination of morphemes can construct a word, while the combination of word can construct phrase or clause. In other word, the writer concludes that morpheme is the smallest part unit in language that can construct words.

\section{Types of Morpheme}

Morpheme consist of free and bound morpheme. Firstly, free morpheme is a morpheme which can stand alone as a word". It means that free morpheme is an independent word that does not need a combination to stand as a word. Secondly, bound Morpheme is a morpheme cannot stand alone". It means that bound morpheme cannot be formed by itself, it needs combination to stand as a word. It can function if the original or basic added affix or grammatical function Lieber (2009).

\section{Affixes}

Affixes are set of letter that is added to the root of word and can be change the part of speech or grammatical function by word (Lieber, 2009). Affixation is a morphological process which supposed to change a root or base word to form a new word. Affixes are classified into two different ways, they are: (1) according to the positions and (2) according to the functions. According to the positions, affixes are divided into three types of affixes; they are prefix, infix and suffix. Prefix is an affix which is attached before a word, infix is an affix which is inserted into a word, and suffix is an affix which is attached after a word. "Affixes can be attached before or after a base".

\section{Derivational Affixes}

Derivation is the process by which the words are formed and create new lexemes, so before making new lexemes, they have to have "the base" because it is the core of word which can be turned into different word by attaching affixes. They are set of letter that is added to the root of word and can be change the part of speech or grammatical function by word. Derivational Affixes have four the classification namely prefix, infix, suffix and circumfix (Lieber, 2009). Prefix is an affix that is added in the beginning of words, for example prefixes 'un-', 're-' and 'dis-' like undress, unexpected, unable, recover, recreate, recount, disappear, disability and many other.

Infix is an affix that are inserted right into a root or base of word, for example In English: absofuckinlutely (abso-fuckin-lutely) this word consist of infix 'fuckin' and the base word is 'absolutely', fanbloodytastic (fan-bloody-tastic) that consists of an infix 'bloody' and the base word is 'fantastic'. Suffix is an affix that is added in the end of base words, for example suffixes '-ness', '- ize' and '-ify' like sadness, goodness, openness, romanticize, hospitalize, finalize, animalize, civilize, classify, purify, diversify, and any more. Circumfix is an affixes that consists of two parts- a prefix and a suffix that together create a new lexeme from a base, for example, In English: enlighten (en-light-en) this word consists of circumfix ('en-' is a prefix, 'light' is the base word and '-en' is a suffix).

\section{Characteristic of Derivational affixes}

Derivational can be easily to be understood by knowing their characteristics. They are listed into three characteristics. Those are derivational affixes always change the part of speech and the meaning of the word, it can call affixation process such as the word sad as an adjective is added by suffix ness become sadness as a noun. Second, derivational affixes always occur in noun, verb and an adjective. Last, derivational affixes usually change the context meaning to the word totally, but in some case, derivational affixes do not change the context meaning and only the part of speech meaning.

\section{Function of the Derivational affixes}


The function of certain derivational affixes is to create new base forms (new stems) that other derivational or inflectional affixes can attach too. In this study, the researcher focusing on the characteristic and function of derivational affixes in writing analytical exposition text. These derived words may give different grammatical function or they just make new words without changing the part of speech (Fromkin, et al, 2014). There are some processes of derivational affixes. According to Fromkin et al. (2014), the derivational affixes are Noun to Adjective: -ish, -ous, -ion, -ate, -ful, -ic boy +- ish - boyish, virtue +- ous virtuous, affect + -ion + affection + -ate - affectionate, health +- ful, alcohol +- ic - alcoholic. Verb to Noun: suffix: -al, -ance, -ation, -er, -ist, -ion, acquitt + -al -acquittal, clear + -ance clearance, accus + -ation -accusation, sing + -er - singer, conform + -ist - conformist, predict + -ion- prediction. Adjective to Adverb: -ly, Exact + -ly - exactly, free + -ly - freely. Noun to Verb: -ize, -ate, -en, im-, be-, en-, in, moral+ -ize - moralize, vaccin + -ate - vaccinate, hast + -en - hasten,im- + prison - imprison, be- + friend - befriend, en- + joy - enjoy, in- +habit inhabit. Adjective to Noun: -ness, -ity, -ism, -dom, tall + -ness - tallness, specific + -ity specificity, feudal + -ism -feudalism, free +-dom - freedom.Verb to Adjective: -able, -ive, ory, -y, read + -able - readable, create + -ive - creative, migrate + -ory -migratory, run $(n)+-$ y - runny. Adjective to Verb: en-, -ize, en + large - enlarge, ideal + -ize - idealize.

Some derivational affixes do not cause a change in grammatical classes (Fromkin et al., 2014). Those include; Noun to Noun: -ship, -ity, -dom, dis-, un, Friend + -ship friendship, human + -ity - humanity, king + -dom -kingdom, dis + advantage - disadvantage, un + employment - unemployment. Verb to Verb: un-, re-, dis-, auto-, Un + do - undo, re - + cover - recover, dis- + believe - disbelieve, auto-+ destruct - autodestruct. Adjective to Adjective: -ish, il-, in-, un-, Pink + -ish - pinkish, il- + legal - illegal, in- + accurate inaccurate, un- + happy - unhappy.

\section{The Classification of Derivational Affixes}

Derivational Prefix is a bound morpheme which attaches to the front of the stem or base word to form a new word or change the meaning of the word. All prefixes in English are derivational, meaning it creates new word. Prefixes usually do not change the class of the base word, but sometimes also there are prefixes that change the class of the base word (Johnson, 2011). An affix that is inserted within a root word and which creates a new word. An infix is usually placed into the root word after the first syllable of the root word. infixation occur in colloquial. Suffixes are a letter or group of letters which is attached to the stem of word and creates a new word, as well as alter the way it functions grammatically. A derivational suffix is a type of suffix that creates a new word; the new word is derived from a base word. There are many kinds of suffix such as -al, -ence, -ance, -er, -ion, -ist, -ation, etc. According to Koltai (2014) form class of derivatives that they produce, suffixes are classification into: nominal suffixes (suffixes forming nouns), verbal suffixes (suffixes forming verbs), adjectival suffixes (suffixes forming adjectives), adverbial suffixes (suffixes forming adverb).

Nominal Suffix is a suffix which is added to the end of base and changes the base into noun. In English there are some suffixes that can be used in forming nouns from noun, verb, and adjective base form. Verbal suffix is a suffix which is added to the end of base and changes the base into verb. In English there are some suffixes that can be used in forming verb from noun and adjective base form. Adjectival suffix is a suffix which is added to the end of base and changes the base into adjective. In English there are some suffixes that can be used in forming adjective from noun and verb base form. Then, the adverbial suffix is a suffix which is added to the end of base and changes the base into adverb. In English there are some suffixes that can be used in forming adjective from noun and adjective base form. 
Derivational Circumfix is a prefix and a suffix attached simultaneously to a root word that performs the single function of creating a new word.

\section{Analytical Exposition Text}

Analytical exposition text is a text which discuss about something that happen in society. The writers give their opinion about the phenomena that will be discussed. Refnaldi (2010) states that "analytical exposition essay is the essay which argues that something is the case".

\section{The Social Function of Analytical Exposition Text}

The social function of the analytical exposition text is to persuade the reader with the writer's opinion about an issue. In line with the above statement, Kartini and Farikah (2015:556) states that the social function of analytical exposition text. Also, it is to persuade the reader that something is the case. Moreover, Refnaldi (2010:217) states that "the purpose of this text is to give acceptable and reasonable argument".

The purpose of Analytical Exposition Text

According to Dahler and Toruan (2017:53) states that the purpose of analytical exposition text into persuade the readers or listeners by presenting the arguments which tell the fundamental reasons why something is the case. Based on the experts' statements above, the writer can conclude that the social function of analytical exposition text is to give the arguments about the topic that happen recently.

\section{The Generic Structure of Analytical Exposition Text}

In writing analytical exposition text, the writer must follow the generic structure of this text. Refnaldi (2010:217) states the generic structure of analytical exposition text. It consists of Thesis $>$ Arguments $>$ Writer's Reiteration. Thesis is a statement of the write's position about a topic that will be discussed and tells what the writer is focusing on. This can be found in the first paragraph. Then, the following paragraph is the supporting points that support the thesis statement. The writer supports the thesis statement by putting the arguments about the topic. Then, the last part is writer's reiteration which reinforces the thesis statement in the first paragraph.

\section{The language Features of Analytical Exposition Text}

The language features of analytical exposition text consist of several parts. Priyana et al (2008:58) state that the common grammatical patterns in analytical exposition text include: General nouns, e.g. ears, zoos; Abstract nouns, e.g. policy, government; Technical words, e.g. species of animals; Relating verbs, e.g. it is important; Action verbs, e.g. we must save; Thinking verbs, e.g. many people believe; Modal verbs, e.g. we must preserve; Modal adverbs, e.g. certainly we must try; Connectives, e.g. firstly, secondly; and Evaluate language, e.g. important, significant, and valuable.

\section{RESEARCH METHOD}

\section{Research Design}

Qualitative research design was used to describe the data analysis in for of words or sentences. According to Bogdan and Biklen (2007:5) as cited in Silalahi E (2015:63) qualitative research is where the data collection in from of words or pictures rather than numbers. The data in this research design previous stated. It refers to data analysis of 
derivational affixes in writing analytical exposition text. It is from words consist of derivational affixes. That why research design is qualitative used in this research.

\section{Data Sources}

The data source of the research were the analytical exposition text made by students. The data of this research was all the words that contain of derivational affixes in writing analytical text that has been finished written by students. The data for this study are taken from You Tube in $19^{\text {th }}$ until $24^{\text {rd }}$ March, $13^{\text {th }}$ may and 28 july 2020 . There was 16 text about analytical exposition that relevant with Corona Virus Disease 19.

\section{Instruments}

The data were collected by searching the students' writing from YouTube (e.g. https://youtu.be/f9s4MRHVUz0). It was done by using laptop and internet. It means that the instrument of data collection in this research was laptop and internet. The writing was selected in form of analytical exposition. They were consisted of 16 texts. The texts were contained of the topic related into corona virus 19 (covid 19).

\section{Data Analysis}

In the data analysis of the research, the researcher using theory according to Lieber (2009) because this theory explained about affixes and whit this theory the researcher just described the derivational affixes in writing analytical exposition text. In data analysis, the researcher took these following steps: Reading and underlying the data with affixes identifying the data related with affixes; Identifying the data related with affixes; Classifying the data into group of affixation; Analysis the process of affixation based on the form and function; and Percentage the process of affixation based on occurrence that found in the data.

Types of Derivational Affixes

\begin{tabular}{|c|c|c|c|c|c|c|}
\hline \multirow{2}{*}{ No. } & \multirow{2}{*}{ Data } & \multirow{2}{*}{ Roots } & \multicolumn{3}{|c|}{ Types of Derivational Affixes } & \multirow{2}{*}{$\begin{array}{l}\text { Note } \\
\text { Formation }\end{array}$} \\
\hline & & & Prefix & Suffix & Circumfix & \\
\hline 1. & $\begin{array}{l}\text { Everyone can protect } \\
\text { themselves from the } \\
\text { spread of the virus } \\
\text { with always wash the } \\
\text { hands correctly. }\end{array}$ & Correct (Adj.) & & $-1 y$ & & Adv. \\
\hline 2. & $\begin{array}{l}\text { Health expert } \\
\text { recommend to wash } \\
\text { the hands with soap } \\
\text { and clean water } \\
\text { around } 15 \text { until } 30 \\
\text { seconds. }\end{array}$ & Commend (V) & Re- & & & Noun \\
\hline 3. & $\begin{array}{l}\text { stay at home is the } \\
\text { most effective way to } \\
\text { prevent the COVID- } \\
19 \text { transmission. }\end{array}$ & Miss (V) & & & trans-ion & Noun \\
\hline
\end{tabular}

\section{RESEARCH FINDINGS AND DISCUSSION}

The objective of this research was to know the derivational affixes in writing analytical exposition text. The research data were taken from all the text in analytical exposition text 
that related corona virus disease 19 from the You Tube. After watching the video and reading the text of the analytical exposition text, in this study researchers showed that there were 159 total words data in the text of analytical exposition from 16 Text which attached derivational affixes.

To answer the research problems, the researcher served the finding of the research of Derivational Affixes in writing analytical exposition text. There are three point explanations.

The data of derivational affixes which are classified based on type of affixes that are prefix, suffix, and circumfix. The total of all prefix that found in analytical exposition is 19 prefixes. The total of all suffix that found in analytical exposition is 124 suffixes. The total of all circumfix that found in analytical exposition is 16 circumfixes. The highest data is derivational suffixes is suffix - ly to form an adverb affix, the total is $33-$ ly suffixes. The second highest data is derivational suffixes -ing to form a noun affix,with the total is 32 -ing suffixes. The third highest data is derivational suffixes is -ed with the total 16 those suffixes. The four highest data is derivational suffixes is -ion, -y, -er with the total between 4 until 6 those suffixes. The five highest is derivational prefix is under- with the total 5 those prefix. The lowest number is derivational affixes pre-, dis-, re-, On-, inter-, micro-, trans-, Over-, al-, In-, out-, -ment, -ness, -ion, -y, -er, -ive, -ous, -ant, -ious, -ation, -en, -wards, -ition, -est, -ies, ities -ily, -ence, -side with the total between 1 until 3 both of them. All the finding of the research is explained more detailed as follow.

The data of prefix which found are pre-, dis-, re-, On-, Under-, inter-, micro-, trans-, Over-, al-, In-, out-, suffix which found are -ment, -ly, -ness, -ion, -y, -er, -ive, -ous, -ant, ious, -ation, -en, -wards, -ition, -ed, -est, -ies, -ities -ily, -ence, -ing, -side, and the last circumfix which found are Trans-ed, In-ation, Inter-ion, Dis-ed, Re-ation, Un-y, Anti-ion, uned, In-ly, Trans-ion, Inter -ed, re-ing, Trans-ing, In- ing, In-ent. To find out the function of affixes found in writing analytical exposition text. It is shown in the table below.

Table 1

The Function of Derivational Affixes

\begin{tabular}{|c|c|c|}
\hline No. & The Function of Derivational Affixes & $\begin{array}{l}\text { The Number of The Function of } \\
\text { Derivational Affixes }\end{array}$ \\
\hline \multirow[t]{4}{*}{ A. } & Verb Formation & \\
\hline & 1. Noun into verb & 18 \\
\hline & 2. Adjective into verb & 3 \\
\hline & 3. Verb into verb & 18 \\
\hline \multirow[t]{4}{*}{ B. } & Noun Formation & \\
\hline & 4. Verb into noun & 37 \\
\hline & 5. Adjective into noun & 4 \\
\hline & 6. Noun into noun & 12 \\
\hline \multirow[t]{5}{*}{ C. } & Adjective formation & \\
\hline & 7. Noun into adjective & 16 \\
\hline & 8. Verb into adjective & 13 \\
\hline & 9. Adverb into adjective & 3 \\
\hline & 10. Adjective into adjective & 2 \\
\hline \multirow[t]{4}{*}{ D. } & Adverb Formation & \\
\hline & 11. Noun into adverb & 2 \\
\hline & 12. Verb into adverb & 4 \\
\hline & 13. Adjective into adverb & 27 \\
\hline
\end{tabular}

The researcher finding was provided into the table. By using the category. The finding was explained below.

Table 2

Affixation Category

\begin{tabular}{ccc}
\hline No. & Affixation Category & Total \\
\hline & The Types of Affixes & 159 \\
\hline
\end{tabular}




\begin{tabular}{cc}
\hline The Structure form of Affixes & 49 \\
\hline The function of Affixes & 13 \\
\hline Total & 221 \\
\hline
\end{tabular}

The finding of this research reveals the process of derivational in writing analytical exposition text. There are some processes of derivational affixes concerned in the finding covering affixes noun to adjective, verb to noun, adjective to adverb, noun to verb, adjective to noun, verb to adjective and adjective to verb. The affixation processes were found in form of prefix, suffix and circumfix. Prefix is placed to the front of root or base of word. Suffix is added to the back part of root or base of word and circumfix is an affix that have two parts, added to both the beginning and the end of word.

Concerning to the finding of derivational affixes which are found in the analytical exposition text as the research object denotes affixes as verb formation, affixes as noun formation, affixes as adjective formation and affixes as adverb formation. It refers to Lieber (2009), Agusmartoyo (2012). Meanwhile, there is no infix which is occurred in the analytical exposition text written by the subjects.

\section{CONCLUSION}

Research finding showed that derivational affixes found in the students' writing of analytical exposition consisted of three types. They were prefix (pre-, dis-, re-), suffix (-ness, -ion, -ious), and circumfix (re-ation, trans-ing, in-ing). Derivational affixes become one of the productive ways in forming English words. The base or root to which affixes are attached can be originated from English. Those affixes can derive new words with various kinds of part of speech and meaning. This will enrich the language source for English language users. Derivational affixes have function to change the meaning of the words different with early words or single words when it was not affixed. The adjectives can be changed into verbs (beauty-beautify). Other changing can be happened in nouns into verbs, adjectives in to nouns, verbs into adverbs.

\section{ACKNOWLEDGEMENT}

This research was conducted to fulfil a requirement for degree of strata one at English Department at FKIP Universitas HKBP Nommensen. In conducting this research, worth idea, suggestion and advised was received by the researcher. For that greatful thanks was addressed to Ibu Dumaris E. Silalahi and Pak David T. Hutahaean Unforgettable thanks to my parents (M.Simaremare and N Sianipar) my sister and my brother (Ermalena, Bistok, Manogari, wagner) for your support me moral and material in completing this research.

\section{REFERENCES}

Aryati, M. S. (2014). An analysis of derivational affixes in the land of five towers novel by a. Fuadi Translated by angiekilbane: English education department Teacher training and education faculty Muria Kudus University.

Bogdan, R. C., \& Biklen, S. K. (1992). Qualitative Research for Education: An Introduction to Theory and Methods. Boston, MA: Allyn and Bacon.

Dechaine. (2012). Linguistics for Dummies. Ontario: John Wiley and Sons Canada.

Donalds, B. (2011). The Definition of Morphology. (http/www.google.co.id). Accessed on 5 th December.

Fasold, R. W. and Linton, J. C. (2014). An Introduction Language and Linguistics. United Kingdom: Cambridge University Press. 
Fromkin, V., Rodman, R., and Hyams, N. (2011). An Introduction to Language. Wadsworth: Cengage Learning. Fromkin, V., Robert Rodman, and Nina Hyams, (2014). An Introduction to affixesLanguage. New York: Michael Rosenberg.

Haspelmath, M., \& Sims, A.D. (2010). Understanding Morphology. London: Hodder Education.

Herman. (2015). Suffixes Found in Narrative Writing at Grade Eight of SMP Methodist Pematangsiantar. Journal of Humanities and Social Science.

Johnson, H. (2011). Types of English Affixes: Derivational and Inflectional Prefixes and Suffixes. Retrieved from https://parentingpatch.com/english-affixes-derivationalinflectional-prefixes-suffixes/

Kartini \& Farikah. (2015). "Analysis of Theme of the Analytical Exposition Texts Written by the Third Semester Students of English Department of Tidar University." International Journal of English and Education. ISSN:2278- 4012, Volume:4, Issue:3.

Koltai, A. (2014). A Big List of Prefixes and Suffixes and Their Meanings . Retrieved from https://www.myenglishteacher.eu/blog/prefixes-suffixes-list/

Littosseliti, L. (2010). Research Method in Linguistics. London: Continuum International Publishing Group.

Lieber, R. (2009). Introducing Morphology.Cambridge: Cambridge University Press.

Maharsi, E. \&Purwaningtyas, I. (2017). Exploring English Morphology: For Elementary Linguistic Learners. Malang: UB Press. novel by a. Fuadi Translated by angiekilbane: English education department Teacher training and education faculty Muria Kudus University.

Priyana. (2008). Interlanguage: English for Senior High School Students XI Science and Social Study Programme. PusatPerbukuanDepartemenPendidikan Nasional: Jakarta.

Untoro, B. (2016). "The Effect of Group Investigation and learning Style on Students' Writing of Analytical Exposition.” Indonesian Journal of English Education. Vol.3, No.1.

Refnaldi. (2010). Essay Writing A Process Genre Based Approach. Padang: English language teaching study program UniveritasNegeri Padang.

Silalahi, D, E. (2015). The English learners' comprehension on figurative language at FKIP UHN Pematangsiantar.journal of English ducation linguistic and literature (JEELL).

Varatharajoo, A. (2015). The Awareness of Morphemic Knowledge for Young Adults' Vocabulary Learning. The Malaysian online Journal of Educational Science. 3(2), 4556. 